\title{
Comparison of Conservative Treatments for Children With Idiopathic Scoliosis
}

\begin{abstract}
Introduction. We evaluated the effectiveness of different methods of conservative treatment modalities for the treatment of idiopathic scoliosis in children.

Patients and Methods. The study included 61 patients with scoliosis. The modalities of physical treatment included exercise, exercise plus traction, exercise plus mider, or a combination of exercise, traction and mider. We evaluated three age groups: patients between 5 and 8 years of age (Group 1), those between 9 and 11 years of age (Group 2) and those between 12 and 14 years of age (Group 3). The follow-up period was three months after the initial treatment, during which all patients continued physical treatment. The outcome was categorized as improved, unchanged or worsened.
\end{abstract}

Results and discussion. After three months of treatment the most frequent outcome was unchanged (62\% of all participants). Exercise was the treatment most frequently applied (54\% of the total group). We found no significant difference in treatment modes and treatment outcomes after three months ( $p>0.05)$. Exercise alone was the most effective treatment for the youngest patients (Group 1). We also noted that a combination of exercises and traction was most effective in patients above 10 years of age; the majority of other patients showed either improvement or unchanged outcomes in curve progression.

Conclusion. Patients with congenital scoliosis should be assessed individually using a multidisciplinary approach. The rehabilitation program should be individually prescribed, implemented daily and should include regular check-ups between three and six months to assess spine curve progression.

\section{KEY WORDS}

Scoliosis, rehabilitation, children, age.

DOI: $10.7251 / S M D 1302086 D Z$

(Scr Med 2013;44:86-9)

\section{Dragana Dzamic ${ }^{1}$, Ivana Petronic, ${ }^{1,2}$, Dejan Nikolic ${ }^{1}$, Dragana Cirovic ${ }^{1,2}$, Tatjana Knezevic ${ }^{1}$, Radivoj Brdar ${ }^{2,3}$}

${ }^{1}$ Physical Medicine and Rehabilitation, University Childrens Hospital, Belgrade, Serbia

${ }^{2}$ Faculty of Medicine, University of Belgrade, Belgrade, Serbia ${ }_{3}^{3}$ Pediatric Surgery, University Childrens Hospital, Belgrade, Serbia

\section{Correspondence}

Dragana Dzamic, $M D, M S c$

Služba Fizikalne medicine i rehabilitacije, Univerzitetska dečja klinika, $1100 o$ Beograd, Serbia email: denikol27@gmail.com

Submitted: April 20, 2013

Accepted: August 15, 2013
Idiopahic scoliosis is defined as a three-dimensional deformity of the spine. ${ }^{1}$ Age is an important determinant for the progression of this deformity. Infantile scoliosis will resolve spontaneously in about $80 \%$ of patients, while in adolescents, scoliosis generally takes a benign course. ${ }^{2}$ The conservative treatment for scoliosis, particularly in children, consists of an exercise program with eventual inclusion of traction and/or mider as needed. Currently, physicians in different countries have different concepts as to the need for physical therapy or surgery. ${ }^{3,4}$ The effectiveness of exercise, particularly for reduction of curve progression, pain onset and as treatments for scoliosis pulmonary dysphunction, was noted previously..$^{5-7}$ A criti- cal review of the complexisity of scoliosis treatment emphasized that the Cobb angle alone should not be the only parameter for estimation of the need for surgery in these patients. $^{8}$

The aim of our study was to evaluate the effectiveness of different methods of conservative treatments for idiopathic scoliosis in children.

\section{Patients and Methods}

Study groups. The study included 61 patients who were referred to the University Childrens Hospital (UCH) for treatment of scoliosis. The average age of the participants 
was $11.8(\mathrm{SD}=2.1)$ years old. The patients were divided into three groups according to age: Group 1 (5-8 years old); Group 2 (9-11 years); Group 3 (12-14 years).

Diagnosis and treatment. Clinical and neurological examinations confirmed the diagnosis of scoliosis, and all patients were followed by X-ray and imaging procedures. Cobbs angle was used to establish the diagnosis of scoliosis and to indicate recommendations for treatment. According to previous recommendations, a Cobbs angle above $10^{\circ}$ was considered to be a scoliotic deformity. ${ }^{9}$ All patients were evaluated by board-certified physicians and pediatric surgeons. Upon confirmation of the diagnosis of idiopathic scoliosis, eligible participants between 5 and 14 years of age were included in the physical therapy program. The physical treatment included: exercise, exercise plus traction, exercise plus mider, and a combination of exercise, traction and mider. Mider was recommended for patients with idiopathic scoliosis when the Cobbs angle was between $20^{\circ}-45^{\circ}$ or when Cobbs angle was between $20^{\circ}-30,{ }^{\circ}$ with $5^{\circ}$ progression between two consecutive measurements. ${ }^{9}$ After considering the type, degree of the curve and the ages of the participants, exercise was the most frequently applied (33 patients, 54\%), exercise and mider (2 patients, $3 \%$ ), exercise and traction (10 patients, $16 \%$ ), and combined treatment (16 patients, 26\%). We grouped patients according to the age of onset of idiopathic scoliosis as described above; the size of each group follows: Group $1-5$ patients, Group 2-11, Group 3-45. The physical treatment for each group was continued regularly for three months. The entire study group was then re-evaluated. The outcome for each individual was categorized as improved, unchanged or worsened.

The study was approved by our Institutional Review Board
Table 1. Effects of various thre months physical therapy programs for treatmen of scoliosis. The patients from all groups are included.

\begin{tabular}{lccc}
\hline Treatment & \multicolumn{1}{c}{ Improvement } & Unchanged & Worsened \\
\cline { 2 - 4 } & $\mathrm{n}$ & $\mathrm{n}$ & $\mathrm{n}$ \\
\hline Exercise (n=33) & 8 & 20 & 5 \\
\hline $\begin{array}{l}\text { Exercise+mider } \\
(\mathrm{n}=2)\end{array}$ & 1 & 1 & 0 \\
\hline $\begin{array}{l}\text { Exercise+traction } \\
(\mathrm{n}=10)\end{array}$ & 2 & 7 & 1 \\
\hline $\begin{array}{l}\text { Exercise+traction } \\
+ \text { mider (n=16) }\end{array}$ & 3 & 10 & 3 \\
\hline Total & 14 & 38 & 9 \\
\hline
\end{tabular}

and was carried out in accordance with good clinical practice. Prior to inclusion in the study, parents or legal guardians were informed as to the study protocol, and informed consent was obtained.

Statistical analysis. The chi-square test was used to evaluate how each treatment mode influenced the outcome. We used Fisher's test to evaluate treatment outcomes between groups and accepted $\mathrm{p}<0.05$ as indicative of statistical significance.

\section{Results}

After three months of treatment, the condition of 38 patients remained unchanged (62\%) regardless of the modality of treatment applied (Table 1). Eight of 33 patients who did exercise alone improved; six of those are from the Group 3. Out of ten patients who had both the exercise and traction program, two showed an improved condition. However, six children from the same group developed a

Table 2. Treatment outcomes of rehabilitation programs related to age

\begin{tabular}{|c|c|c|c|c|}
\hline \multirow{2}{*}{ Program } & \multirow{2}{*}{ Age groups* } & Improved & Unchanged & Worsened \\
\hline & & $\mathrm{n}$ & $\mathrm{n}$ & $\mathrm{n}$ \\
\hline \multirow{4}{*}{ Exercise } & Group 1 & 1 & 3 & - \\
\hline & Group 2 & 1 & 6 & - \\
\hline & Group 3 & 6 & 11 & 5 \\
\hline & Total & 8 & 20 & 5 \\
\hline \multirow{4}{*}{$\begin{array}{l}\text { Exercise \& } \\
\text { Traction }\end{array}$} & Group 1 & - & 1 & - \\
\hline & Group 2 & - & - & - \\
\hline & Group 3 & 2 & 6 & 1 \\
\hline & Total & 2 & 7 & 1 \\
\hline \multirow{4}{*}{$\begin{array}{l}\text { Exercis \& } \\
\text { Traction \& } \\
\text { Mider }\end{array}$} & Group 1 & - & - & - \\
\hline & Group 2 & 1 & 2 & - \\
\hline & Group 3 & 2 & 8 & 3 \\
\hline & Total & 3 & 10 & 3 \\
\hline
\end{tabular}

*Group $\mathbf{1}$ =5-8 years; Group $\mathbf{2}$ = 9-11 years; Group $\mathbf{3}$ = 12-14 years 
worsened condition. The combination of an exercise program with traction and mider resulted in an improvement of three children (Table 2). Of the two patients assigned to treatment with both exercises and mider (Group 1 and Group 2), one improved and the other experienced no change in condition. There were no significant differences of the results obtained with different treatments in the defined age groups.

\section{Discussion}

Our findings indicate that that exercise is effective for all patients who were diagnosed with idiopathic scoliosis, while inclusion of other treatment modes, such as mider or traction, does not necessarily influence the outcome or course of treatment. These results are consistent with previous findings that exercise as physical therapy for patients with scoliosis was more effective for prevention of curve progression than other treatments. ${ }^{10}$ However, it is important to emphasize that further evaluation of the extent and type of exercise is needed to establish the most effective treatment for scoliosis. It was shown previously that an individual approach to the patients with individually adapted exercises is more effective than the usual physiotherapy protocol. ${ }^{11}$

Given the previous findings on the effectiveness of exercise, we believe that treatment could be improved by individual prescription of the type and extent of exercise. In addition, each treatment program should be tailored to the individual with scoliosis, depending upon more parameters present at evaluation than by assessment of the Cobbs angle alone.

Numerous published studies indicate that different modules of treatment are prescribed for different ages of patients with diagnosed idiopathic scoliosis. ${ }^{8,12,13}$ Even though we found no statistical significance between the different rehabilitation modes within the defined age groups, we suggest that different modules of rehabilitation may influence, to some degree, the treatment outcome. We noted that exercise in combination with traction was most effective in patients older than 9 years; curve progression in the majority of those patients either improved or remained unchanged. Aside from the effectiveness of exercise, these slightly older patients may be more cooperative as to the proper implementation of their therapy.

The small number of patients limited our study, so any future study should include a larger number of participants. Since we included only those patients with idiopathic scoliosis, additional investigations should also include other types of scoliosis.

In conclusion, young patients with idiopathic scoliosis should be assessed individually using a multidisciplinary approach. Regardless of additional treatments, such as mider or traction, exercise appears to be the most impor- tant component in the conservative treatment of idiopathic scoliosis. Each rehabilitation program should be individually prescribed, implemented daily and include regular check-ups and timely follow-up until the termination of skeletal growth.

\section{Author's Contribution}

DĎ̌-article writing, critical revisions, therapy design; IP-physical examination, article writing, reference search; $D N$ - article writing, methodological postulations, critical revisions; DC therapy follow-up, literature search; TK - methodological postulations, critical interpretation of results; $R B$ - orthopedic examination, diagnostics.

\section{Conflict of interest}

Authors declare no conflict of interest.

\section{Rerefences}

1. Parent S, Newton PO, Wenger DR. Adolescent Idiopahhic: etiology, anatomy, natural history, and bracing. Instr Course Lect 2005; 54:529-36.

2. Trobisch P, Suess O, Schwab F. Idiopathic scoliosis. Dtsch Arztebl Int. 2010;107(49):875-83.

3. Hawes MC. The use of exercises in the treatment of scoliosis: an evidence-based critical review of the literature._Pediatr Rehabil 2003;6:171-82.

4. Weiss HR, Negrini S, Hawes MC, et al. Physical exercises in the treatment of idiopathic scoliosis at risk of brace treatment -SOSORT consensus paper 2005. Scoliosis 2006;1:6.

5. Weiss HR, Bickert W. Improvement of the parameters of rightheart stress evidenced by electrocardiographic examinations by the in-patient rehabilitation program according to Schroth in adult patients with scoliosis. Orthop Prax 1996; 32:450-3.

6. Ferraro C, Masiero S, Venturin A. Effect of exercise therapy on mild idiopathic scoliosis. Preliminary result. Europa Medico Physica 1998;34:25-31.

7. Negrini S, Antonini G, Carabalona R, et al. Physical exercises as a treatment for adolescent idiopathic scoliosis. A systematic review. Ped Rehab 2003;6:227-35.

8. Weiss HR, Goodall D. The treatment of adolescent idiopathic scoliosis (AIS) according to present evidence. A systematic review. Eur J Phys Rehabil Med 2008;44:177-93.

9. Kim H, Kim HS, Moon ES, et al. Scoliosis Imaging: What radiologists should know. RadioGraphics 2010;30:1823-42.

10. Romano M, Minozzi S, Bettany-Saltikov J, et al. Exercises for adolescent idiopathic scoliosis. Cochrane Database Syst Rev 2012; 8:CDoo7837.

11. Negrini S, Zaina F, Romano M, et al. Specific exercises reduce brace prescription in adolescent idiopathic scoliosis: a prospective controlled cohort study with worst-case analysis. J Rehabil Med 2008;40:451-5.

12. Lincoln TL._Infantile idiopathic scoliosis. Am J Orthop (Belle Mead NJ) 2007;36:586-90.

13. Morin C.Treatment of idiopathic scoliosis in children during the growth period. Bull Acad Natl Med 1999;183:731-5. 


\title{
Poređenje konzervativnog tretmana kod dece sa idiopatskom skoliozom
}

\begin{abstract}
APSTRAKT
Uvod: Ispitivana je efikasnost različitih metoda konzervativne terapije u tretmanu dece sa idiopatskom skoliozom.

Pacijenti i metode: Ispitivanjem je obuhvaćeno 64 dece sa skoliozom. Vrste fizikalne terapije koje su primenjivane su: vežbe, vežbe sa trakcijom, vežbe sa miderom ili kombinacija vežbi, trakcije i midera. Praćene su 3 uzrastne grupe: pacijenti između 5-8 godina života (Grupa 1), između 9-11 godina života (Grupa 2) i pacijenti između 12-14 godina (Grupa 3). Period praćenja je bio 3 meseca od početka tretmana. Ishod konzervativne terapije je kategorisan kao: poboljšanje, nepromenjeno stanje ili pogoršanje.

Rezultati i diskusija: Posle 3 meseca od početka terapije u 62\% slučaja je došlo do poboljšanja. Najčešće su primenjivane vežbe kao tip tretmana (54\%). Nije nađena značajna razlika u ishodu tretmana u odnosu na tip terapije (p>0.05). Samo vežbe su najefikasniji metod terapije u mlađoj grupi ispitanika (Grupa 1). Pokazano je da je kombinacija vežbi i trakcija najefikasnija metoda u lečenju dece preko10 godina života.

Zaključak: Pacijente sa idiopatskom skoliozom treba individualno analizirati uz multidisciplinarni pristup. Rehabilitacioni program treba biti individualno dizajniran i svakodnevno ga treba sprovoditi uz redovne kontrole između 3 i 6 meseci.
\end{abstract}

\section{KLJUČNE REČI}

Skolioza, rehabilitacija, deca, uzrast. 